\title{
Nuevos rumbos humanos: experiência do tempo e figurações do "novo" na revista La Biblioteca (1896-1898)
}

\author{
Mauro Franco Neto ${ }^{1}$
}

\begin{abstract}
Resumo: a partir de uma análise da revista La Biblioteca (1896-1898), importante espaço de confluência intelectual na Buenos Aires finissecular, o desafio que se coloca é pensar como aqueles letrados agenciavam sua relação com o tempo e a história, particularmente nas avaliações que faziam a respeito da insurgência de um "novo tempo" e seus respectivos sintomas, bem como nas revisões acerca do passado e projeções e imagens criadas sobre o futuro.
\end{abstract}

Palavras-chave: tempo; experiência; história

\section{Nuevos rumbos humanos: experience of time and figurations of the "new" in the journal La Biblioteca (1896-1898)}

\begin{abstract}
From an analysis of the Journal La Biblioteca (1896-1898), an important place for intellectual meeting sin the late nineteenth century in Buenos Aires, the topic under discussion is to think on how those intellectuals imagined their relationship with time and history, particularly in evaluations that they made on the insurgency of a "new era" and their respective symptoms, as well as the reviews about the past and projections and images created on the future.
\end{abstract}

Keywords: Time; Experience, History

Artigo recebido em: 16/02/2016

Artigo aprovado para publicação em: 19/05/2016

Em estudo sobre a obra de Voltaire, Roland Barthes argumentou que o escritor setecentista teria sido "o último escritor feliz". (BARTHES, 2014, p. 1) Tudo era espetáculo em suas batalhas: o nome do adversário, sempre ridículo; a doutrina combatida, reduzida a uma

\footnotetext{
${ }^{1}$ Doutorando em História pelo PPGHis da Universidade Federal de Ouro Preto. Este artigo é resultado parcial de dissertação de mestrado defendida no Programa de Pós-graduação em História Social da Cultura da PUC-Rio e foi financiado pelo CNPq. Agradeço pela leitura e orientação à Prof. Dra. Maria Elisa Noronha de Sá (PUC-Rio) e ao Prof. Dr. Marcelo de Mello Rangel (UFOP). E-mail: franconeto.m@ hotmail.com.
}

\section{CANPHLAC}

Revista Eletrônica da ANPHLAC, ISSN 1679-1061, №. 21, p. 232-260, Jul./Dez., 2016.

http://revista.anphlac.org.br 
proposta; a profusão de tiros acertando em todas as direções. Menos que uma filosofia ou uma explicação, seu recurso para enfrentar certos temas eram a ironia e o estranhamento. Desse modo, afirma Barthes, "o escritor estava do mesmo lado da história, tão feliz que ele a sentia como um coroamento, não como um excesso ao qual corria o risco de ser conduzido". (BARTHES, 2014, p. 3)

Se, por outro lado, os letrados oitocentistas a todo o momento serão obrigados a se haver com a história e a ação do tempo, não podendo negligenciar o seu peso, para Voltaire era ainda possível conquistar a felicidade e a simplicidade a partir de uma suspensão do tempo e do apoio numa certa imobilidade do mundo. Fundamentalmente, entre os fatos marcantes da história só existiria uma relação de contiguidade, não de função: “a oposição de Voltaire a toda inteligência do Tempo é muito viva". Não haveria história tal como a conhecemos, mas "um encontro de acasos, aqui Dragonadas, ali Racine".

O ponto nodal de uma modificação na responsabilidade do escritor teria sido colocado por Rousseau e a ideia de um movimento constante da história, oferecendo ao escritor um presente envenenado do qual ele deveria se isolar. A partir daí, "sedento e tocado por uma responsabilidade que não poderá ser mais nem completamente honrada, nem completamente evitada, o intelectual vai se definir por sua má consciência”. Se os conhecesse, Voltaire teria reservado uma fina ironia aos adeptos dos "ismos" que preencheram o século XIX. Para estes homens, a história já estava vestida com a roupagem de um grande drama.

Se a angústia do escritor oitocentista pode ser identificada mesmo naqueles autores que pareciam perfeitamente ajustados com as transformações do seu tempo - afinal, sempre cabia a eles explicarem o porquê do atraso da satisfação plena -, um grupo em especial foi capaz de aglutinar os temores e desconfianças para com um tempo que se fazia cada vez mais convulsionado. Tocqueville, Renan e Taine expressaram suas dissensões quanto aos valores que seriam característicos da linguagem desse "novo tempo", isto é, a democracia como um problema social, o igualitarismo, a ciência e o seu materialismo, dentre outros.

Em carta ainda pouco posterior aos conturbados dias de 1848 na França, o autor de $A$ Democracia na América expunha sua consternação: "La ola sigue marchando. El mar sube. [...] Se siente que el viejo mundo concluye; pero ¿cuál será el nuevo?” (TOCQUEVILLE Apud TERÁN, 2000, p. 40) Uma face deste "novo" seria a democracia "rompedora", a democracia

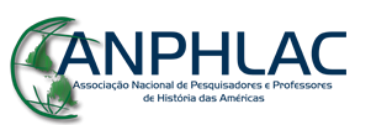

Revista Eletrônica da ANPHLAC, ISSN 1679-1061, №. 21, p. 232-260, Jul./Dez., 2016.

http://revista.anphlac.org.br 
que quebra uma dada ordem e, assim, "hace olvidar a cada hombre a sus abuelos; le oculta sus descendientes y lo separa de sus contemporáneos. Lo conduce hacia sí mismo y amenaza con encerrarlo en la soledad de su propio corazón.” (TOCQUEVILLE Apud TERÁN, 2000, p. 41)

A seu modo, Taine entrou em conflito com alguns valores como a perda da totalidade do homem antigo e a conformação de uma sociedade democrática onde imperava a alienação das massas. Resgatou, contudo, a fé na ciência, mas não como instrumento de domínio sobre o mundo e sim como “alimento espiritual e uma nova fé" (TERÁN, 2000, p. 34).

Analogamente, Renan, após visitar a exposição universal de 1855, julgou preocupante a extensão que tomava a técnica e definiu sua época como "decadente em su materialismo y su culto democrático de la tecnologia ofrecida a las masas como panem et circenses". Anos depois, em 1871, às portas "de las dolorosas semanas" da Comuna de Paris, Renan se virava contra ideologias radicais, a mediocridade e o materialismo, denunciando a democracia: "el más enérgico disolvente de toda virtud que el mundo haya conocido hasta aquí". (TERÁN, 2000, p.40)

A percepção de um descompasso entre os rumos tomados pela história e o que ela, em tese, deveria ser, configurando-a como propriamente um fardo, foi expressa pelo argentino Miguel Cané (1851-1905) na definição de que o mundo moderno era fundamentalmente um mundo cansado e que pesava sobre ele "la ciencia de veinte siglos y la tremenda responsabilidad de um porvenir incerto." (CANÉ Apud TERÁN, p. 37)

Cané nasceu em Buenos Aires e desenvolveu seus estudos no Colegio Nacional entre 1863 e 1868. Sua carreira como publicista ganhou vida em periódicos como o El Nacional e o La Tribuna. Foi ainda deputado, senador e diplomata, deixando escritos sobre História, Política, Literatura e Direito. A relação entre o peso da história e a responsabilidade do letrado é central na sua obra.

A história só assume essa face porque o letrado parece incapaz de dotar de sentido esse conjunto de transformações em voga. Ou melhor, o "porvenir incierto" de que fala Cané, isto é, a impossibilidade de dar continuidade a determinados valores que a história e a experiência legaram, é o que a colocava como um algoz do qual o letrado sempre parecia estar na contramão. Tornava-se comum então a produção de anomalias e situações embaraçosas como aquela presenciada por Cané em 1897 quando passava por Paris e relatou sua visão de um automóvel

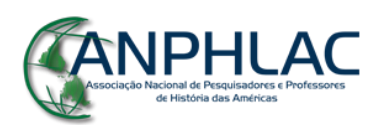

Revista Eletrônica da ANPHLAC, ISSN 1679-1061, №. 21, p. 232-260, Jul./Dez., 2016.

http://revista.anphlac.org.br 
como um "espectáculo desgraciado de un coche sin caballos, moviéndose sin gracia, como um cuerpo humano amputado, que se arrastra hábil y desairadamente" (CANÉ Apud TERÁN, p. 37).

Miguel Cané compôs o que se costuma chamar de generación del 80 em Buenos Aires, ao lado de nomes como Paul Groussac, Lucio Vicente Lopez, os irmãos Ramos Mejía, Eduardo Wilde, dentre outros. Tendo como tema central os descaminhos da construção da nação e do processo de modernização do país, essa geração de letrados se organizou em um espaço onde foi possível conviver, segundo o historiador Oscar Terán, várias matrizes de orientações política e culturais desde o romantismo "acriollado" da Geração de 1837, o liberalismo, além de concepções católicas, socialistas e anarquistas (TERÁN, 2000, p.13). A historiografia registrou este primeiro momento como de intenso entusiasmo com os feitos econômicos e políticos e que a contínua agitação que dilacerara o país pela maior parte do século XIX estava superada pela consolidação do Estado Nacional. Situação que se inverte, porém, a partir da crise financeira desencadeada em 1890 a partir da qual irão se proliferar os diagnósticos do atraso argentino face o processo de modernização. Vejamos alguns depoimentos mais detalhadamente.

Oscar Wilde, em carta ao então presidente Julio Roca, relatava com euforia suas impressões acerca do futuro argentino: "Adelante, adelante. Haremos de Buenos Aires la Atenas de Sudamérica" (WILDE Apud TERÁN, 2005, p.15). Ou mesmo a opinião de Cané que, num primeiro momento, mostrava-se mais acolhedor para com os princípios do progresso: "Por aquí todo marcha bien. El país en todo sentido se abre a las corrientes del progreso, con una gran confianza en la paz y la tranquilidad pública e una fe profunda en el porvenir." (CANÉ Apud TERÁN, 2005, p.15). Tal entusiasmo tinha respaldo direto, novamente segundo Terán, numa realidade que revelava a consolidação institucional da nação (aliviando o antagonismo entre, por exemplo, duas facções como a do nacionalismo mitrista e do autonomismo de Alsina), o crescimento econômico, a possibilidade real de ascensão social a alguns setores e uma exitosa secularização social impulsionada pelo Estado (TERÁN, 2005, p.16.)

Tal cenário só foi possível, em grande medida, devido a características de origem econômica como a incorporação de várias terras férteis, "cuja utilização tornou-se economicamente viável em razão de a diminuição dos custos de transporte ter aproximado da Argentina o mercado dos países europeus, aumentando demanda para as exportações." (LENZ,

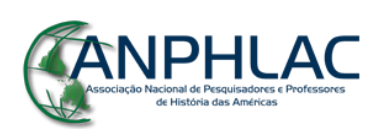

Revista Eletrônica da ANPHLAC, ISSN 1679-1061, №. 21, p. 232-260, Jul./Dez., 2016.

http://revista.anphlac.org.br 
2006, p. 376) Não se pode subestimar, contudo, a chegada da mão de obra imigrante, a construção de estradas de ferro e, sobretudo, de aporte de capital estrangeiro, especialmente de origem britânica. Isto porque tal medida acarretará, além de outras consequências, no aumento da dívida externa do país, de modo que em 1890 se chega ao gasto total de 60 milhões de pesos de ouro (LENZ, 2006, p. 386) com o pagamento da dívida criada para a impulsão da economia na década anterior.

A deflagração da crise acontece propriamente quando Londres sinaliza para a impossibilidade de adiar o pagamento do montante da dívida argentina. Os efeitos no cenário argentino são de grande crise social e de agitação política que culminam na renúncia de Miguel Juárez Celman (1896-1890) e na subida de Carlos Pellegrini (1890-1892) ao poder (GARULI, 2011).

\section{Para além de diários e folhetins: a La Biblioteca e a temporalidade própria das revistas}

Ao lado de Cané, um conjunto de escritores e letrados, sempre a convite do diretor Paul Groussac, compuseram uma importante plataforma de reflexão neste período finissecular, a saber, a revista La Biblioteca. Neste texto, a partir de uma análise dos oito tomos da revista que saíram entre 1896-1898, o desafio que se coloca é pensar como aqueles letrados agenciavam sua relação com o tempo e a história, particularmente nas avaliações que faziam a respeito da insurgência de um "novo tempo" e seus respectivos sintomas, bem como nas revisões acerca do passado e projeções e imagens criadas sobre o futuro.

Nas últimas duas décadas do século XIX, ficaram registradas algumas empresas editoriais através de revistas ${ }^{2}$, tais como a Nueva Revista de Buenos Aires de Ernesto Quesada, a Revista de Derecho, Historia y Letras de Estanislao Zeballos e a Revista Nacional de Adolfo Carranza. (BRUNO, 2005, p. 74) La Biblioteca de Paul Groussac dá continuidade a essa tradição do periodismo intelectual bonaerense e foi capaz de reunir a um só tempo os principais letrados da capital, dentre eles Bartolomé Mitre, Vicente Fidel Lopez, Lucio Vicente Lopez,

\footnotetext{
${ }^{2}$ Importante aqui distinguir a revista do jornal diário que circulava pelas ruas da capital. São alguns exemplos da década de 1890 o La Nación de Bartolomé Mitre, o El Nacional de Miguel Cané e Aristóbulo del Valle, o El Diário de Manuel Láinez e o La Unión de Pedro Goyena e J. M. Estrada.
}

\section{CANPHLAC}

Revista Eletrônica da ANPHLAC, ISSN 1679-1061, №. 21, p. 232-260, Jul./Dez., 2016.

http://revista.anphlac.org.br 
Rubén Darío, Miguel Cané, Juan Agustín García, Roque Saenz Peña, Carlos Pellegrini. Sua contribuição se faz assim imprescindível para a reconstrução da multiplicidade de relatos e vivências que compunham aquela experiência letrada finissecular.

Na aparição de La Biblioteca em 1896, o seu diretor anunciava que o órgão seria mensal e visava publicar artigos inéditos. A cada dia 15 a revista aparecia então em "cuadernos de octava mayor", com 160 páginas que, ao final de quatro meses, conformariam um tomo de 640 páginas. O que vimos, porém, foi a reunião trimestral desses números, totalizando oito tomos entre 1896 e 1898.

A sua capa já trazia a inscrição "Historia, Ciencia, Letras", tríade recorrente também em outras revistas, além do nome do diretor Groussac e a editora "Librería de Felix Lajouane", responsável pela vasta maioria das publicações bonaerenses de então. Ao longo desses oito tomos, apenas três seções permaneceram fixas: "Boletín Bibliográfico", no qual Groussac resenhava as principais novidades editoriais do trimestre; "Documentos Históricos", onde expunha fontes arquivadas no acervo da Biblioteca Nacional; e "Redactores", essa última o local onde Groussac traçava, por vezes com severas críticas, um esboço biográfico de cada colaborador. Paula Bruno, biógrafa de Paul Groussac, relatou as diversas tarefas do diretor no periódico, assumindo a posição de um juiz da cultura intelectual argentina:

\footnotetext{
Seleccionar los escritos, escribir los comentarios bibliográficos e los 'redactores' le permitía impulsar o censurar trayectorias, establecer límites entre lo aceptable y lo prescindible del mundo de las producciones culturales, señalar quiénes eran para él protagonistas destacados de la intelectualidad argentina y quiénes, decididamente, no lo eran. (BRUNO, 2005, p.79)
}

\section{CANPHLAC}

Revista Eletrônica da ANPHLAC, ISSN 1679-1061, №. 21, p. 232-260, Jul./Dez., 2016.

http://revista.anphlac.org.br 


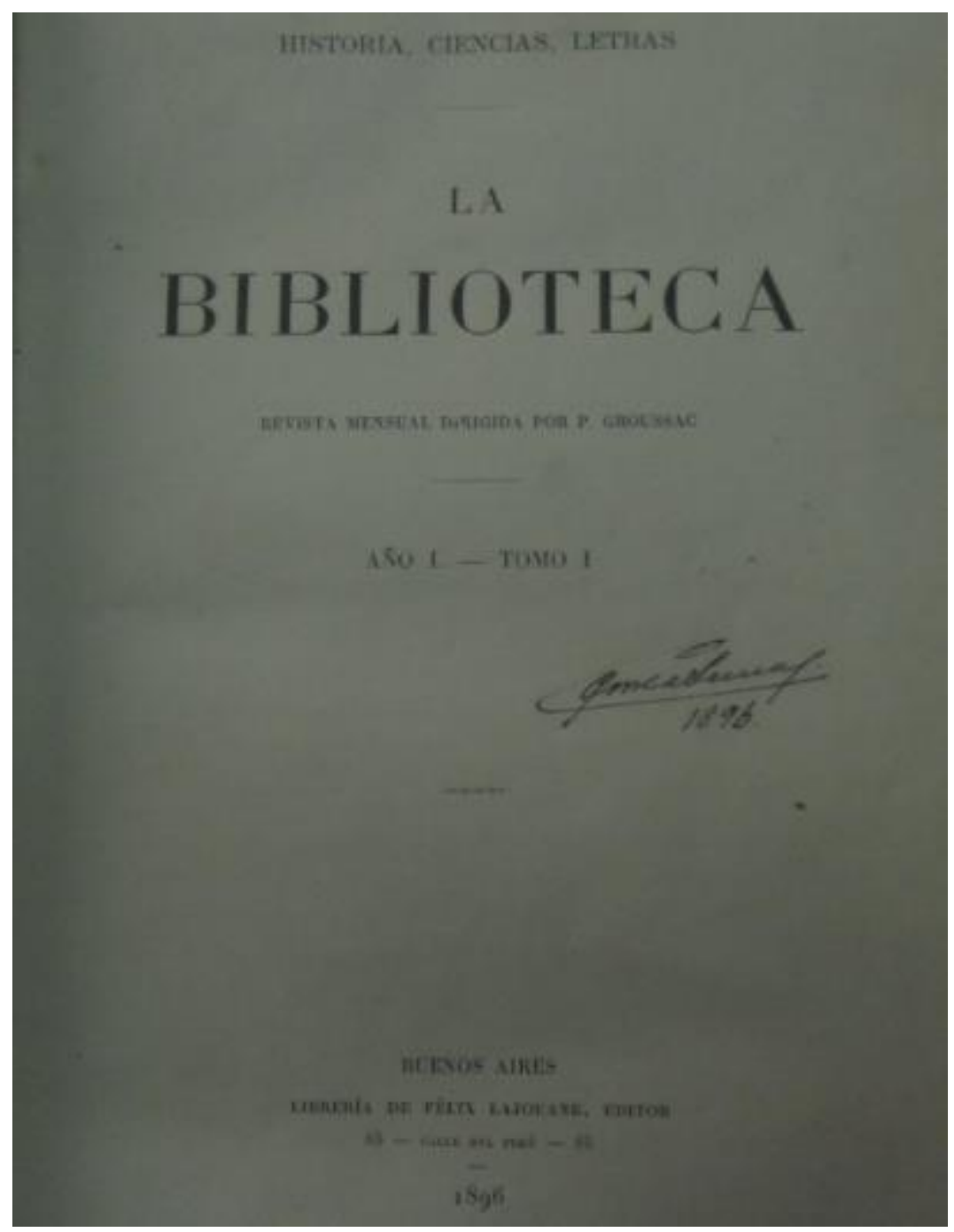

Capa da primeira edição da revista La Biblioteca que circulou em junho de 1896.

O diretor anuncia também outra seção que deveria ser fixa, mas que sequer apareceu uma única vez: a "Crónica del mes". Tal espaço seria o responsável por dar o toque de atualidade para a revista, relatando os acontecimentos conjunturais do mundo político e da ordem social e econômica. ${ }^{3}$ Neste sentido, é possível argumentar que a revista se parecia muito mais com um livro fragmentado do que propriamente com o jornal diário. Aliás, não foram poucas as obras que mais tarde ganhariam a forma de "livro", mas vieram a público pela

\footnotetext{
${ }^{3} \mathrm{~A}$ crônica, enquanto uma forma de autorreflexividade de um sujeito literário então nascente em finais do século XIX, certamente não caiu no gosto de Paul Groussac. Por vezes, foi visível seu descontentamento com a efemeridade, ou mesmo impotência para ir além da tarefa noticiosa do cotidiano. A Groussac interessava mais gêneros com uma maior perenidade frente à "força destruidora do tempo".
}

\section{CANPHLAC}

Revista Eletrônica da ANPHLAC, ISSN 1679-1061, №. 21, p. 232-260, Jul./Dez., 2016.

http://revista.anphlac.org.br 
primeira vez no modo serial que a revista propunha, funcionando como um verdadeiro laboratório da recepção pública.

A diferenciação com o jornal, por sua vez, será ressaltada pelo diretor, principalmente pelo corte erudito da revista e avesso à forma sintética e efêmera do primeiro. Em uma das raras incursões de Groussac em um tema mais próximo do seu presente, uma correspondência entre Mitre e Irigoyen sobre uma possível candidatura do primeiro nas eleições de 1891, o diretor de prontidão ressalta que o argumento que irá desenrolar não é de forma alguma uma tomada de posição política. A revista teria como escopo de interesse a ciência, a literatura e a história, cravando sua propaganda apenas na serena região das ideias e "dejando que otros se ocupen de lo que pasa, para dedicarnos por entero á lo que queda" (GROUSSAC, 1896, p. 64).

O relato feito por Groussac de uma experiência ao mesmo tempo anedótica e reveladora pela qual passou, traz à tona os elementos que envolviam as tentativas de diferenciação entre a revista, o jornal diário e até o escarnecido folhetim. Segundo nos conta, ao passar pela casa de um amigo na parte da manhã e não encontrá-lo já de pé, pôs-se a conversar com sua esposa, assim definida, "elegante, risueña, con su gracia casi tímida que la hace más simpática, que interrumpió la lectura de La Nación [o diário] para recebirme” (GROUSSAC, 1896, p. 64). Poucos minutos depois, tendo ido a esposa despertar o “dormilón”, Groussac afirma ter deixado escapar um olhar para o diário, onde ali aparecia em destaque uma chamada para o próximo número da revista La Biblioteca. Tudo dentro do esperado, a não ser por logo abaixo encontrar o anúncio de um "folletín”: Paris, de Émile Zola.

Sem entrar propriamente no mérito da oposição de Groussac ao ímpeto inovador da poética naturalista por sua dita busca por unir o herói às piores espécies sociais e com o vício, o folhetim como gênero, e em especial aquele de Zola, era, segundo Groussac, absolutamente contraindicado para aquela "inconsciente señora nascida y criada en una atmosfera de honradez y delicadeza moral". Ali se encontravam alusões "á aventuras de tal orden pornográfica que es imposible transcribir en uma revista decente" (GROUSSAC, 1896, p. 64). O folhetim e o jornal diário, como sintoma das novas redes de sociabilidade da burguesia portenha - no caso das formas materiais que esta sociabilidade assumia -, ao tratarem da banalidade do cotidiano, de um tempo curto e efêmero, não alcançavam sensibilidades fundamentais que só a revista

\section{CANPHLAC}

Revista Eletrônica da ANPHLAC, ISSN 1679-1061, №. 21, p. 232-260, Jul./Dez., 2016.

http://revista.anphlac.org.br 
poderia trazer. No dizer de Groussac, obras de ciência e arte "no se elaboran en bulevares y en los clubes" (GROUSSAC, 1897, p. 313).

A relação da revista com o tempo é ainda mais interessante se notarmos que o intervalo entre 1896 e 1898 é propriamente limitado para definir seu escopo de atuação. Ou seja, através do trabalho de Groussac em recolher e publicar textos inéditos de autores que construíram a história argentina no XIX, e através também da colaboração de escritores que ficaram marcados por gerações anteriores, La Biblioteca pode ser descrita como um ponto de encontro de vários momentos da história intelectual argentina. Nas palavras do historiador Ricardo Rojas, a revista reuniu "viejos maestros nativos - Mitre y López - que aún vivían - con los nuevos escritores de las más diversas especialidades”. (ROJAS Apud BRUNO, 2005, p.78) Neste sentido, a historia literária chamou a atenção para a convivência entre figuras próximas ao modelo do "letrado" e alguns dos "novos" escritores que por então se iniciavam no caminho da profissionalização. ${ }^{4}$

A confluência de gerações é ainda visível por intermédio da comparação das experiências que cada grupo pôde presenciar. Há entre os colaboradores aqueles nascidos no primeiro quartel do século XIX que vivenciaram todas as implicações da consolidação do Estado nacional argentino, desde o período Rosas e até mesmo a Guerra do Paraguai. E há um segundo grupo nascido nas décadas de 1850 e 1860, estimulado por outros debates e com uma carreira pública e letrada com menos restrições políticas e uma necessária passagem pelo ambiente universitário.

\footnotetext{
${ }^{4}$ A transformação da figura do letrado, aqui descrita, faz referência a um movimento que somente pode ser entendido na diacronia das representações anteriores de figuras dominantes da cultura, segundo o historiador Cristophe Charle. Assim, a conquista de legitimidade do campo intelectual ocorreu de maneira gradual, passando pelo elitismo de certas figuras correspondentes a um campo intelectual fechado em si, até uma transformação do campo intelectual nas décadas finais do século XIX com a expansão das profissões intelectuais, um crescimento do público e uma contestação das hierarquias culturais mais antigas. Do homem de letras iluminista e do poeta romântico, passando pelos "savants" que transitavam nas múltiplas formas do saber, chega-se a uma nova divisão do trabalho intelectual em que os novos modelos simbólicos se remetem à profissionalização e ao elogio da especialidade intelectual. $C f$. CHARLE, Christophe. Naissance des "intellectuels" (1880-1900). Paris: Éditions de Minuit, 1990.
}

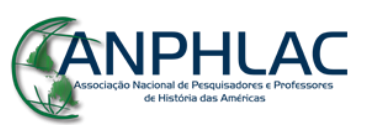

Revista Eletrônica da ANPHLAC, ISSN 1679-1061, №. 21, p. 232-260, Jul./Dez., 2016.

http://revista.anphlac.org.br 


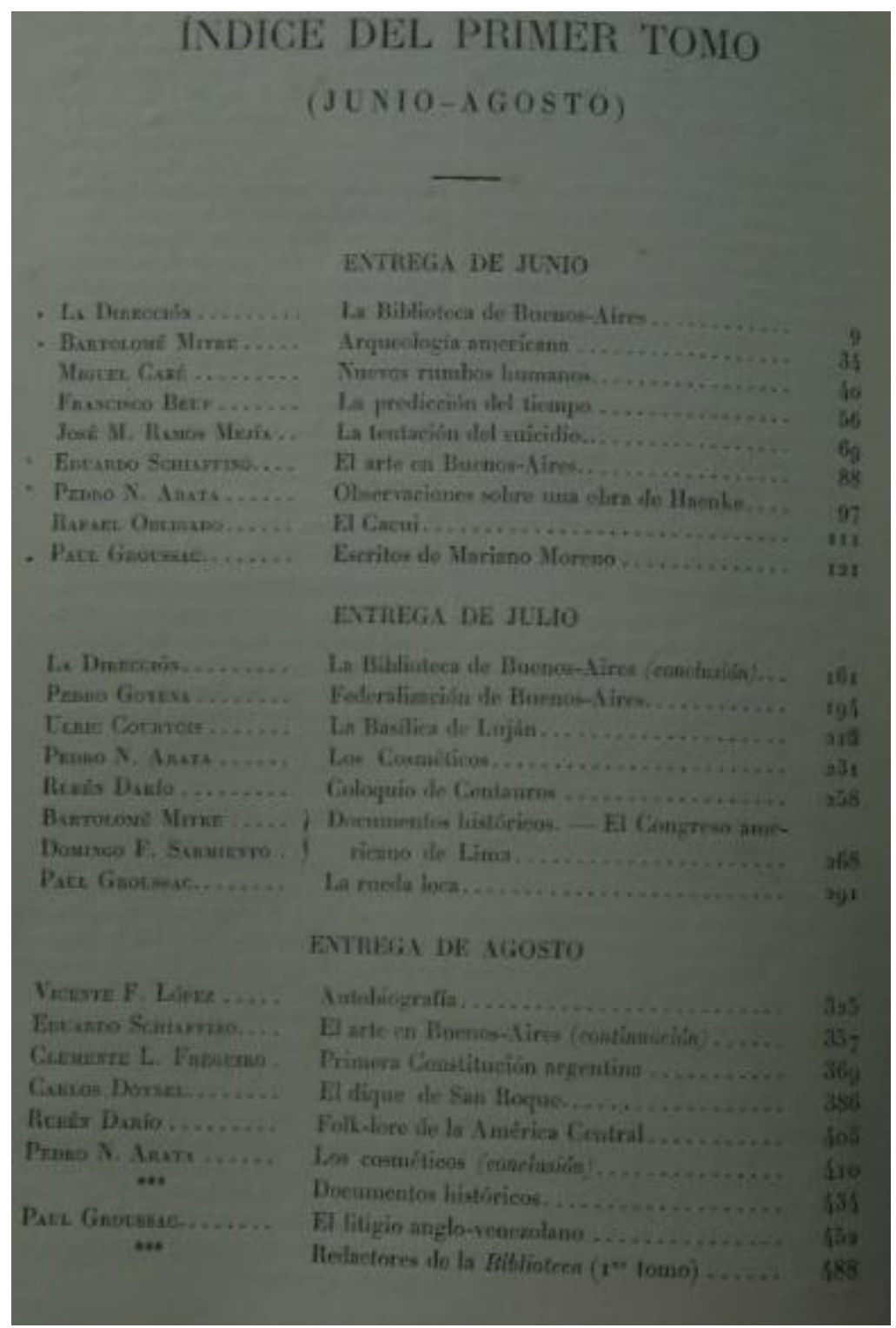

Índice do primeiro tomo da revista que reunia as publicações dos três meses iniciais.

Grosso modo, seus temas tratavam de questões científicas e culturais, com a decisiva presença de personagens ligados às Faculdades de Direito e Medicina da Universidade de

\section{GANPHLAC}

Revista Eletrônica da ANPHLAC, ISSN 1679-1061, №. 21, p. 232-260, Jul./Dez., 2016.

http://revista.anphlac.org.br 
Buenos Aires ${ }^{5}$, além de atores do universo político argentino e outros publicistas ${ }^{6}$. Ao final de cada tomo, onde Groussac apresentava uma breve biografia dos colaboradores, ficam claras algumas recorrências nesses perfis. Aliás, mesmo que seja uma aproximação feita por exceções, a trajetória característica do homem público argentino de então é a formação na Faculdade de Direito, o início da carreira política que, em casos, pode culminar na alta cúpula e, ainda, as incursões em escritos de natureza historiográfica e literária. A relação de La Biblioteca com as duas faculdades mais prestigiadas da Universidade de Buenos Aires é sensível. ${ }^{7}$ Os representantes das principais cátedras das Faculdades de Direito e Medicina legam seus escritos que, por repetidas vezes, versam sobre os temas mais distantes às suas formações. E isto à revelia do diretor Paul Groussac que, como veremos posteriormente, faz radicais críticas ao impulso híbrido do letrado argentino de então.

Na carta de abertura da revista - uma espécie de editorial - são dois os questionamentos sobre o projeto de La Biblioteca que o diretor relata ouvir. De um lado, a dificuldade em encontrar colaboradores para preencher suas páginas, a ausência de preparação intelectual e de tempo livre do letrado, para além de suas outras funções. De outro, a escassez de leitores caso a revista se distanciasse da improvisação diária e noticiosa, aqui em referência ao jornal. Dúvidas um tanto quanto recorrentes ao pensamento latino americano oitocentista. É ao notar o pessimismo das restrições àquele campo intelectual que o lugar de enunciação da revista se torna mais claro. Isto é, o empreendimento de Groussac com a revista era observado como uma

\footnotetext{
${ }^{5}$ Não é demais recordar que a Faculdad de Filosofia y Letras da Universidade de Buenos Aires só ganha uma faceta institucional em 1896, algo que, de um modo ou de outro, revela a dificuldade da institucionalização de áreas como a filosofia e a literatura na tradição letrada argentina. Por outro lado, é possível ainda identificar que a emergência da Faculdade aponta para uma fratura entre a letra (o "saber dizer", retórica, características do contexto letrado anterior) e a lei (racionalizado). Em outras palavras, a criação da faculdade em 1896, mesmo ano da fundação da revista La Biblioteca, sinaliza para uma quebra na unicidade da autoridade letrada argentina.

${ }^{6}$ Categoria ampla e utilizada então para descrever letrados que atuavam na esfera pública por intermédio dos jornais, revistas ou mesmo nos debates parlamentares.

${ }^{7}$ Aliás, a década de 1890 é apontada pela historiadora Paula Bruno como um momento de complexificação das antigas formas da sociabilidade letrada que predominavam em Buenos Aires: "Por un lado, el 'momento 1890' había abierto un nuevo ciclo en la vida política y pública de Buenos Aires y del país en su totalidad. Por otra parte, también los espacios educativos universitarios se encontraban ya en un estado de mayor consolidación; es posible pensar, entonces, que, junto con las sociabilidades culturales que respondían a la idea de círculo o ateneo, las discusiones centrales se daban, a la par, en ámbitos institucionales formales, como la Facultad de Derecho y Ciencias Sociales y la Facultad de Medicina de la Universidad de Buenos Aires. De hecho, el auge de las ciencias sociales y el despliegue de una cultura científica son dos fenómenos que se vinculan estrechamente con la vida universitaria." BRUNO, Paula. Sociabilidades culturales en Buenos Aires, 1860-1930. Revista Prismas, vol. 16, $\mathrm{n}^{\circ} 2$, dez. 2012.
}

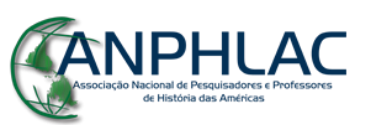

Revista Eletrônica da ANPHLAC, ISSN 1679-1061, №. 21, p. 232-260, Jul./Dez., 2016.

http://revista.anphlac.org.br 
legítima tarefa de modernização das letras argentinas. É o que relata Miguel Cané em carta ao diretor logo após a publicação do primeiro número:

\begin{abstract}
Mi querido amigo: recibo el primer número de la Biblioteca junto a su carta. Aún antes de abrirla, el atractivo esterno de la revista me ha producido una grata sensación de frescura, de limpiesa civilizada, que se siente al entrar á la sala de la ópera, por ejemplo, después de haber codeado en las calles una manifestación parroquial. (CANÉ Apud BRUNO, 2005, p. 77)
\end{abstract}

\title{
Democracia e a "questão social"
}

Como observado anteriormente a partir dos relatos de Toqueville, Taine e Renan, um extenso vocabulário ganha força ao longo do século XIX para dar conta de uma nova configuração da experiência do tempo. Na Argentina, os efeitos dessa nova configuração receberam diversas avaliações e foram experimentados de múltiplas formas. A hipótese aqui destacada é a de que há diversas formas de se enfrentar a transformação e as inaugurações de novos cenários, e que a revista é particularmente interessante pela multiplicidade de relatos que produz. Há, no entanto, uma sensível recorrência de certa melancolia e pessimismo entre os letrados argentinos finisseculares que os levavam a algumas narrativas da experiência que não afastavam a possibilidade da decadência e da queda. Tal hipótese procura restituir a complexidade inerente a cada tempo histórico e problematizar interpretações que, a princípio, não consideram as dimensões trágica e dramática contempladas por aquela experiência ou mesmo o conjunto de temores daqueles agentes frente a um tempo sempre mais instável e acelerado.

De volta a Miguel Cané - e tal como boa parte de seus contemporâneos -, este letrado ocupou diversas funções políticas, tendo sido eleito Senador e ocupado cargos diplomáticos na América do Sul e na Europa. Foi também decano da Faculdade de Filosofia e Letras inaugurada em 1896, na mesma Universidade de Buenos Aires onde se graduou em Direito no fim da década de 1870. Incorporou de tal forma as tensões constituintes daquela cultura letrada chamada a cena para pensar os novos projetos de nação em um país desafiado pelos desejos de modernização e suas contradições políticas e sociais. Ainda, na década de 1880, mostrava todo

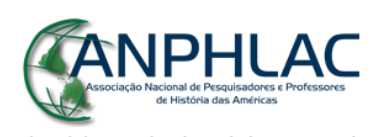

Revista Eletrônica da ANPHLAC, ISSN 1679-1061, №. 21, p. 232-260, Jul./Dez., 2016.

http://revista.anphlac.org.br 
seu otimismo com a construção das bases legais do país no intervalo de apenas algumas décadas após a independência:

Recibimos un mundo nuevo, bárbaro, despoblado, sin el menor síntoma de organización racional: ¡mírese la América de hoy, cuéntense los centenares de millares de extranjeros que viven felices en su suelo, nuestra industria, la explotación de nuestras riquezas, el refinamiento de nuestros gustos, las formas definitivas de nuestro organismo político, y digásenos qué pedazo del mundo ha hecho una evolución semejante en medio siglo! (CANÉ Apud TERÁN, 2000, p. 14)

Este Cané que ainda iniciava sua carreira como publicista, colaborando em órgãos como La Tribuna e El Nacional, militando em favor do partido autonomista do presidente Julio Roca, parece, contudo, anos luz de distância daquele que irá partilhar com seus pares o diagnóstico profundo da crise que perfazia os anos posteriores a 1890. Principalmente, o fortalecimento do vocabulário da "questão social", muito em virtude dos tumultos políticos gerados pela imigração maciça e pelos movimentos antioligárquicos da virada do século, levaram Cané rumo a uma definição pessimista do caminho tomado pelo país.

Na revista La Biblioteca, a convite do diretor Paul Groussac, a síntese dessa percepção de Cané apareceu em artigo ainda no número inicial da revista, em junho de 1896, sob o título "Nuevos Rumbos Humanos". O que podemos ver ali é um Cané estabelecendo uma radical separação entre sua juventude intelectual e a época da maturidade onde agora se encontraria. É com uma dose de ironia que ele se refere às suas fases intelectuais antecedentes, marcadas por posições fortes e bem resolvidas sobre vários temas:

\footnotetext{
8 A “questão social" guarda raízes num fenômeno particular ao mundo moderno, denotado por relativo embaralhamento das esferas política e social que, anteriormente desvinculadas, passam agora a ter significados bem próximos, especialmente num dado "interesse social” sobre o mundo político. Segundo Hannah Arendt, havia entre os gregos uma divisão razoavelmente bem delineada entre uma organização política do espaço público, dada a própria natureza política do homem como zoon politikon, e uma organização doméstica representada pela casa (oikos) familiar onde se lutava pelo resguardo do "social", isto é, das necessidades biológicas para a manutenção da vida. O que interessa mais diretamente aqui é o momento da definitiva incorporação dessa dimensão social pelo universo político na modernidade, com a elevação daquela anterior obrigação doméstica a um nível público, mais diretamente com a expansão dessa esfera política agora representando uma híbrida definição de "sociedade". Particularmente, é também nesse momento que a "questão social" passa a se constituir como um desafio a ser solucionado no interior do campo político, principiando assim um vocabulário que passa a representar essa questão como símbolo de um "novo tempo", de um tempo de inaugurações e rupturas com uma dada ordem. A radicalização desse movimento teria então sido deflagrada pela linguagem revolucionária da segunda metade do século XVIII. $C f$. ARENDT, Hannah. O homem: animal social ou político. In: A condição humana. $10^{\circ} \mathrm{ed}$.
} Rio de Janeiro: Forense Universitária, 2007.

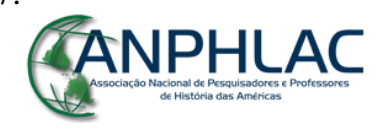

Revista Eletrônica da ANPHLAC, ISSN 1679-1061, №. 21, p. 232-260, Jul./Dez., 2016.

http://revista.anphlac.org.br 
También yo como la mayor parte de los que estas líneas lean, he atravesado la edad soberana por excelencia, aquella en la que se profesan ideas claras, netas y precisas sobre todas las cuestiones capitales de la vida humana. En la que poco se duda, todo se afirma, y en la que la voz de la experiencia suena como nota falsa en los oídos habituados á la rotundidad sonora de las afirmaciones absolutas. Es un fenómeno que ocurre allá por los veinte años y que dura más ó menos tiempo, según la previa posición individual para resistir, dentro del ideal, á los rudos y repetidos golpes de la vida positiva. (CANÉ, 1896, p. 40)

Como uma carta "á mis jóvenes lectores argentinos", o texto de Cané se coloca como uma espécie de sobreaviso a respeito das "fases de esa crisis (...) que, cual más, cual menos, pasarán todos por la misma" (CANÉ, 1896, p.42). Exemplos dessa fase crítica seriam dois autores que na sua maturidade intelectual passaram a adotar uma postura de desconfiança quanto a alguns pressupostos que ganhavam força naquele contexto: Tocqueville e Stuart Mill lançaram o alerta contra a predominância da "questão social" nos debates públicos e os "peligros que ese triunfo definitivo podría traer para el progreso humano" (CANÉ, 1896, p.42).

Para o primeiro, responsável por revelar à Europa "el curioso fenómeno de la democracia natural" encontrado nos Estados Unidos, não tardaria muito até chegar a época em que a subida irresistível das massas encontraria o continente europeu. Para o segundo, a Inglaterra, seu país, só não estava imersa ainda no tema da questão social "precisamente por ese andar pausado de la historia inglesa, ese respecto profundo á lo pasado que solo se rinde á la inovación cuando ésta ha penetrado ya en los costumbres.” (CANÉ, 1896, p.43) A menção ao costume e à experiência, enfatizado por Cané, surge como recurso de descrédito para com a perenidade da democracia para qualquer circunstância. Sendo a democracia algo "natural", o exemplo norte americana se justificava por ter ali surgido "del seno de esse pueblo, por causas tan lógicas com las que determina nel clima de una región”. (CANÉ, 1896, p.42) Retomando o velho binômio entre o espírito e a letra, a democracia, primeiro deveria surgir nas estruturas de comportamento de uma sociedade para só depois se cristalizar como um fato legal.

De um modo geral, Cané e seus pares partilhavam um conceito de democracia como um fenômeno muito próprio ao mundo moderno e, por vezes, também traduzido na palavra "igualitarismo". Como uma espécie de espectro que amedrontava a sociedade moderna, a democracia mais parecia para alguns autores um processo homogeneizador que acabava por "nivelar por baixo" e, segundo o qual, apenas a mediocridade seria possível. Tal visão se aproxima certamente daquela construída por um autor como Groussac a respeito do

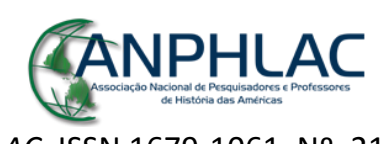

Revista Eletrônica da ANPHLAC, ISSN 1679-1061, №. 21, p. 232-260, Jul./Dez., 2016.

http://revista.anphlac.org.br 
protagonismo dos Estados Unidos na nova ordem mundial. Isto porque a sociedade americana sinalizava para certa predominância de gostos, ideias, aptidões e funções sociais homogêneas na qual seu progresso material teria como equivalente direto o regresso moral. (TERÁN, 2005, p. 23)

A preocupação e o temor de Miguel Cané tinham raízes naquela que seria a última fronteira para essa linguagem obscura e rompedora da "questão social" ultrapassar, isto é, o plano legal, o plano das instituições. Uma vez que os pressupostos dessa questão fossem institucionalizados, todas as portas se abririam para a imprevisibilidade. Daí seu clamor, a exemplo de Stuart Mill, pelo respeito ao passado, pela garantia da continuidade, face ao perigo da aceleração de uma nova ordem desconhecida.

$\mathrm{Na}$ realidade, menos que negar os avanços sociais que o tempo vinha garantindo aos trabalhadores, e Cané reconhecia o progresso neste sentido, afirmando que "hoy, es tal la condición material del obrero, del agricultor, que habría sido um sueño ahora um siglo" (CANÉ, 1896, p.44), o que o autor duvidava radicalmente era da capacidade das instituições políticas de serem as responsáveis por essas mudanças. Neste sentido, do ponto de vista do bem estar humano, pouca diferença haveria entre "pueblos que gozan de instituciones democráticas, y aquellos que se mantienen aún bajo el régimen monárquico" (CANÉ, 1896, p.44). Do mesmo modo, as revoluções e todas as formas abruptas de desestabilização pouco efeito tiveram se comparadas com modificações mais lentas que vão paulatinamente se sedimentando na tradição:

\footnotetext{
La revolución francesa, con sus declaraciones, sus derechos políticos, sus sacudimientos, sus grandezas y sus horrores, habría sido estéril para la humanidad, como lo fueron las de 1640 y 1688 de Inglaterra, si no hubiera precedido por pocos años aquel esfuerzo de la inteligencia humana que, con la física, la química y la mecánica, iba á transformar la faz del universo. (CANÉ, 1896, p.44)
}

Cané faz então uma opção por um tempo de transformações em longa duração. Retira do evento sua capacidade transformadora para apostar num câmbio mais conservador. Ou melhor, faz opção por um evento revolucionário que não tire a possibilidade de vislumbrar um futuro estável: "El espíritu revolucionário, no, no es la adhesión (...) de un Americano á la revolución de 1776, de un Francés á la revolución de 1789; es el amor por las revoluciones sin término." (CANÉ, 1896, p.53)

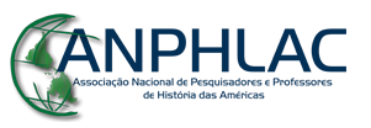

Revista Eletrônica da ANPHLAC, ISSN 1679-1061, №. 21, p. 232-260, Jul./Dez., 2016.

http://revista.anphlac.org.br 
Sua percepção negativa da triunfante democracia evidencia as dúvidas e tensões que compunham efetivamente aquele vocabulário da "questão social". Como já dito, a tentativa de desacreditar a mudança através da institucionalização parece ter sido o recurso encontrado pelo autor para moderar e suavizar o ritmo da volubilidade do seu tempo. A institucionalização era a última porta a ser aberta. Seu temor era respaldado por um traço geral que todas as revoluções na história traziam, segundo ele, "por su carácter destructor y su incapacidad absoluta para definir y precisar el ideal nuevo que encarna" (CANÉ, 1896, p.48). O passado é então apropriado por Cané como forma de alerta sobre a inconsequência de todo ato na história. ${ }^{9}$ Foi assim com os bárbaros marchando sobre o mundo romano, com a Europa investindo nas Cruzadas e quatro séculos mais tarde, "entre sueños y proselitismo" (CANÉ, 1896, p.48), sobre a América: "movimientos colectivos inconscientes" (CANÉ, 1896, p.48) que revelavam, sobretudo, a possibilidade iminente da decadência.

Dessa forma, os "nuevos rumbos humanos" que neste final de século procuravam fortemente imprimir ao processo histórico a velocidade e imprevisibilidade indesejadas por Cané, apenas revelavam para o autor que o progresso material não era acompanhado pelo progresso moral. Era assim que o niilismo russo não desejava uma reforma, mas a morte do czar. Ao mesmo tempo, o anarquista francês ria da democracia e das garantias individuais, tal como os socialistas alemães e os huelguistas da Inglaterra (CANÉ, 1896, p.47).

Seria reduzir a complexidade da postura de Miguel Cané classificá-la como puramente conservadora, tal como faria uma tradicional história das ideias. Não que ela deixe de ser, mas a tarefa de restituir a um contexto as tensões que o constituem, leva-nos a questionar o que possibilitava ao autor reproduzir aquele vocabulário e como era possível a ele dar sentido àquele conjunto de transformações em voga. A imigração maciça em Buenos Aires e a expansão da

\footnotetext{
${ }^{9}$ Seja dito ainda que a dúvida sobre o impulso transformador da "questão social" foi feito em várias frentes. Em uma delas, Paul Groussac desacredita o conceito de "povo" mobilizado pelo vocabulário revolucionário, fundamentalmente pelas imprecisões e o caráter vago a ele inerente. Afinal, quem era o povo? Não faria sentido então imputar a uma dada "vontade geral" a ação na história, quando na realidade quem agiria de fato era apenas um pequeno grupo de ilustrados. GROUSSAC, Paul. Estebán Echeverría. La Biblioteca, Tomo IV, 1897, p. 290. Ainda sobre esse tema, Groussac parece reagir a um conceito organicista de "povo" que tomou forma principalmente a partir da consolidação do Estado nacional argentino, após os anos 1860, quando ganharam força narrativas sobre a pré-existência de uma nação e um povo argentino desde o período colonial. Nessas narrativas, prevalece a concepção da nação como um organismo pré-formado e com um dado objetivo final imputado ao seu destino, de modo que o "povo" nada mais seria que um conjunto sem muita distinção a atuar obscuramente na história. PALTI, Elías. El momento romántico: nación, historia y lenguajes políticos en la Argentina del siglo XIX. Buenos Aires: Eudeba, 2009.
}

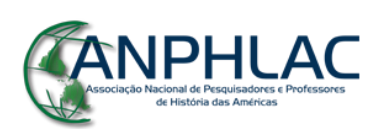

Revista Eletrônica da ANPHLAC, ISSN 1679-1061, №. 21, p. 232-260, Jul./Dez., 2016.

http://revista.anphlac.org.br 
participação política das massas eram fenômenos de amplo rearranjo social que marcavam algo inédito naquela sociedade.

De modo concreto, os dados sobre a profunda transformação pela qual passava a Argentina nas décadas finais do XIX registram que se até o período entre 1871-1880 o número de imigrantes não passava de 50.000, a partir de 1881, e em particular em 1886, pela política de "pasajes subsidiados, chegava em 1889 alcançar a cifra de 289.014 em todo o país". (BERTONI, 1992, p. 78) Na capital, segundo o historiador Fernando Devoto, a população total que era de 187 mil pessoas em 1869 passa a 433 mil em 1887. Os italianos foram ainda os principais responsáveis por esse aumento passando de 44 mil a 133 mil no mesmo intervalo de tempo. (DEVOTO, 2008, p. 96) Por certo, a imigração maciça não deixou de trazer consigo um conjunto de crises de várias ordens, como aquela identitária na qual se manifestaram alguns sentimentos como a crítica a respeito da qualidade dos imigrantes e desconfiança sobre a sua possível integração, de modo a redesenhar o que se entendia pela própria nacionalidade. (BERTONI, 1992, p. 78)

Aliás, as grandes contradições do modelo de modernização socioeconômica adotado pelo governo argentino nos anos 1880 - principalmente pela contração de empréstimo com o capital estrangeiro - parecem ter apresentado a conta na década 1890. Se a aposta na exportação de produtos primários e na importação de manufaturas e recursos humanos criou um clima de exaltação nacional, uma grande massa de trabalhadores, alijada das benfeitorias do desenvolvimentismo, concentra-se nas cidades e formava um incipiente proletariado urbano. $\mathrm{O}$ "movimento obrero", predominantemente anarquista e socialista, ao não ver cumpridas suas demandas por ascensão social, questiona frontalmente a hegemonia política e funda o primeiro partido de massa do país em 1891, a Unión Cívica Radical, partido que estará na linha de frente das principais agitações políticas da capital na década de 1890. (GARULLI, 2011)

Cané não negligencia ${ }^{10}$ essa situação e encontra na metáfora do organicismo o repertório para imprimir sentido a todo esse "cambio", de modo que apenas uma sociedade preparada nas

\footnotetext{
${ }^{10}$ Em estudo sobre a obra de Miguel Cané, o historiador Fabio Muruci identifica que ao mesmo tempo que Cané rejeitou as propostas de participação política das massas de imigrantes, continuando a defender a permanência no poder das elites tradicionais que formaram a "ordem conservadora" do período roquista, também defendeu que esta elite não deveria se tratar de uma casta fechada, e sim de uma elite aberta à incorporação e formação de homens de talento e cultura. SANTOS, Fabio Muruci. Arielismo e liberalismo nos escritos de viagem de Miguel Cané e Oliveira Lima. Revista Anos 90, Porto Alegre, v. 16, n. 29, jul. 2009, p. 125-153.
}

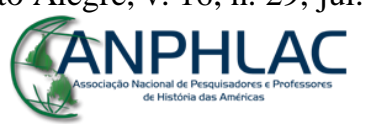

Revista Eletrônica da ANPHLAC, ISSN 1679-1061, №. 21, p. 232-260, Jul./Dez., 2016.

http://revista.anphlac.org.br 
suas raízes para transformações pode absorver o conteúdo daquele desejo de mudança: “él arból crece porque sus raíces están em tierra fecunda, y el fenómeno del desenvolvimiento de ese pueblo responde á causas ajenas á la influencia de su constitución política.” (CANÉ, 1896, p. 54) Da mesma maneira, o "etapismo" que a solução organicista proporciona como forma de moderação às ambições de ruptura sintetiza a postura de Miguel Cané sobre o que seriam os "nuevos rumbos humanos": "Y el remédio, entonces? (...) la cultura moral del individuo, que determinará la cultura y la inteligencia de la masa. El átomo caracteriza al cuerpo (...).”(CANÉ, 1896, p. 54).

No interior de alguns diagnósticos da crise, talvez nenhuma narrativa tenha ganhado contornos tão dramáticos como aquela do diretor Paul Groussac. Desembarcando em Buenos Aires no ano de 1866, o francês Paul Groussac (1848-1929) logo entrou em contato com importantes nomes da cena intelectual argentina como José Manuel Estrada e Pedro Goyena, que então dirigiam a Revista Argentina. Com diversas participações em periódicos da época, Groussac também iniciou a carreira docente e logo a de inspetor nacional de Educação. Sua meteórica carreira ganhou o ponto alto em 1885 quando foi nomeado diretor da Biblioteca Nacional e de lá, através de empreendimentos como a aqui estudada revista La Biblioteca, pôde gerir as diretrizes da cultura letrada argentina finissecular. Colecionou polêmicas com nomes importantes da cultura argentina de então como Bartolomé Mitre e Norberto Piñero (com este último em conflito que pôs fim às edições de La Biblioteca), especialmente por seu incômodo com o ímpeto holístico desses personagens que não admitiam a especificidade da tarefa letrada, confundindo-as com questões estritamente políticas. (BRUNO, 2005)

Cada aparição sua nas páginas de La Biblioteca vinha acompanhada de um lamento pela perda de uma dada experiência que estaria sendo suplantada pela mediocridade do efêmero. $\mathrm{O}$ resgate de certos temas históricos por parte do autor são então fundamentais. É neste sentido que no interior de uma sociedade que se revelava cada vez mais massificada, Groussac se debruça sobre a grandeza do "indivíduo" na história e, mais particularmente, nas condições necessárias para o surgimento do chamado "Héroe" ou "Hombre de Genio", aquele capaz de subverter as ordens de uma sociedade paralisada. ${ }^{11}$

\footnotetext{
${ }^{11}$ Trata-se, segundo o próprio autor, do capítulo de uma obra em preparação intitulada "El problema del génio em la ciencia y em la história"

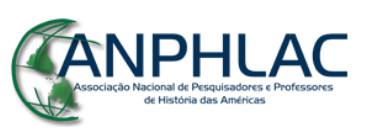

Revista Eletrônica da ANPHLAC, ISSN 1679-1061, №. 21, p. 232-260, Jul./Dez., 2016.

http://revista.anphlac.org.br
} 
Todavia, acontece que "la civilización actual está incubando los hombres de genio" (GROUSSAC, 1897, p. 139), principalmente pela forma niveladora do seu principal valor, a democracia: "La democracia conquistará la alta civilización, como los Hunos el mundo latino. (...) Su triunfo es inevitable. Será el más completo y pesado de los despotismos: el despotismo de la mediocridad". (GROUSSAC, 1897, p. 139) Isso não implicaria que essa nova sociedade não tivesse também seus homens de gênio, mas ao invés de Malebranche, aponta Groussac, cultuariam Santa Teresa.

O sentimento de perda de Groussac, porém, só toma vigor com o crescimento do principal difusor do ideal democrático, aquele que acentuaria o reino da efemeridade frente a valores que deveriam resistir ao tempo - o jornal diário: "Salud al gran educador de la democracia! Su majestad el Diario, - en latín Ephémeris. Nace, circula y muere en un mismo día; (...) simboliza la mentira, la ignorancia, la fatuidad.” (GROUSSAC, 1897, p. 604) A revista, por outro lado, teria como escopo de interesse a ciência, a literatura e a história, "dejando que otros se ocupen de lo que pasa, para dedicarnos por entero á lo que queda. (GROUSSAC, 1897, p. 604, itálico do autor)

É preciso tempo. Parece que esta é a grande motivação do seu lamento. Onde a experiência se esfacela sempre mais velozmente parece ser preciso algum ponto de parada para avaliar o que deve permanecer e resistir àquele ímpeto transformador. Na realidade, é preciso tempo, mas, principalmente, é preciso resistir ao tempo, opor-se a ele. Utiliza então do recurso da relatividade de todas as posições, o que ele anteriormente já havia chamado de "fina reserva y fria ironia" para desacreditar todo intuito transformador que, no fundo, nada mais eram que juízos construídos sobre a imprecisão e a fugacidade do presente. A impossibilidade de se extrair valores sólidos desses juízos tinha como princípio algo muito claro - a estreiteza do presente: "Estamos clavados em el momento actual, que no es sino um punto de la curva infinita." (GROUSSAC, 1897, p.143)

Existia aqui para Groussac um problema de natureza lógica. No interior de uma sociedade que se prometia cada vez mais emancipada e madura, o que ele encontrava nos principais valores desse "novo tempo"12, como a democracia e o jornal diário, era apenas a

\footnotetext{
12 Para uma investigação mais completa a respeito das imagens do "novo" na cultura argentina oitocentista, $c f$. GOLDGEL, Víctor. Cuando lo nuevo conquistó América. Prensa, moda y literatura en el siglo XIX. Buenos Aires: Siglo XXI, 2013. Nesta obra, Goldgel aborda as múltiplas transformações culturais ressignificadas a partir da ideia
}

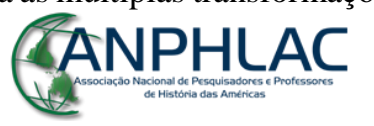

Revista Eletrônica da ANPHLAC, ISSN 1679-1061, №. 21, p. 232-260, Jul./Dez., 2016.

http://revista.anphlac.org.br 
eternização do erro e do engano: "toda la historia contemporânea - ese vasto y contradictorio reportage - está nadando en pleno sueño enganador" (GROUSSAC, 1897, p.151). O fato da mutabilidade em si mesma adquirir características positivas - mudar bastava - produzia em Groussac a percepção de que toda essa roda da mudança acabava por voltar sempre no mesmo lugar, isto quando não decaía: “Ayer el artículo del diário mataba el capítulo del libro; he aqui ahora al despacho y la interview telegráfica que matan al artículo, em cual si quiera algunas veces tenía firma, es decir aparencia de responsabilidad." (GROUSSAC, 1897, p.151)

A constatação é sintomática: as alegorias desse novo tempo, ao invés da prometida emancipação, ofereciam apenas exemplos de que as sucessivas cadeias do processo evolutivo jamais alcançam a maturidade: "La pobre humanidad, efímera cadena de generaciones que se renuevan y suceden sin que ninguna llegue á la madurez, no puede suportar a la verdad desnuda: procura inventar alegorias que mezan y engañen sus tristezas." (GROUSSAC, 1897, p.145) A postura ao mesmo tempo cética e irônica de Groussac, que nada via naquele vocabulário inovador além da dificuldade dos seus contemporâneos em aceitar a miséria humana, não era algo isolado e provavelmente era repercussão de uma forma de se posicionar perante essas transformações que anos antes Lucio Victorio Mansilla já anunciava:

La civilización consiste en que haya muchos médicos y muchos enfermos, muchos abogados y muchos pleitos, muchos soldados y muchas guerras, muchos ricos y muchos pobres. En que se impriman muchos periódicos y circulen muchas mentiras. (MANSILLA Apud TERÁN, 2000, p. 21)

Por vezes, a fala de Groussac acaba por ganhar mesmo um tom apologético no sentido de um chamado à causa para a resistência ao curso da história. Aliás, se quase sempre cético a tomar posições, uma brecha parece se abrir quando o tema era o crescimento do apelo democrático: "Em cien años, la desbordada democracia ha invadido el mundo, cada vez más agresiva y disolvente, batendo en brecha á la religión y la sociedad, á la patria y la família.” (GROUSSAC, 1897, p. 324) Portanto, a ação que valeria a pena, mesmo que o processo desencadeado pela aparição da democracia fosse irreversível, seria propriamente a resistência e a queda de pé a esse novo mundo adoecido, decadente e a beira de um cataclisma: "aunque

do "nuevo" como valor absoluto. Para tanto, Goldgel se concentra em três frentes: o surgimento de um novo meio (o periódico), a consolidação de um dispositivo social que opera uma renovação constante (a moda) e duas formações discursivas (o Iluminismo e o Romantismo) que buscarão legitimar-se como sintoma da novidade.

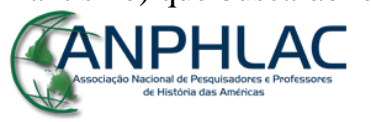

Revista Eletrônica da ANPHLAC, ISSN 1679-1061, №. 21, p. 232-260, Jul./Dez., 2016.

http://revista.anphlac.org.br 
fuera ineluctable el cataclismo en que haya de perecer esta civilización cristiana, sería deber nuestro defenderla y perecer bajo sus ruínas" (GROUSSAC, 1897, p. 324).

Essa reação também é visível por ocasião da Guerra Hispano-americana em $1898^{13}$, como resultado da intervenção dos Estados Unidos no processo de independência de Cuba frente à Espanha, quando Paul Groussac faz um verdadeiro manifesto bélico de apoio à esquadra espanhola, frente ao "yankismo democrático, ateo todo ideal": "confío como otras veces em el arrojo de los soldados españoles y la pericia de sus jefes (...) Viva España con honra!" (GROUSSAC, 1898, p. 240) Se a Doutrina Monroe e o projeto expansionista dos Estados Unidos na América ganhavam cada vez mais força no final do século XIX, o alerta de Groussac para com os limites dessa civilização estaria na confusão que ela estabelecia entre progresso histórico e desenvolvimento material. O impasse fundamental aqui é uma disputa sobre o conceito de evolução que está em jogo. Para Groussac, e talvez também para Cané, o dilema estava em que a evolução, ao menos na concepção que ganhava força naquele vocabulário, não garantira o aprimoramento esperado: a democracia americana "aplica á su modo el principio darwinista de la selección" (GROUSSAC, 1898, p. 237).

O expoente máximo da civilização americana e seu instrumentalismo no campo da filosofia seria o fatídico autor do "evangelio popular del enriquecimiento", Benjamin Franklin, que escreveu: "el hombre es un animal que hace ferramientas". (GROUSSAC, 1898, p. 238). Com seus valores - substituição da razão pela força, a generosidade pelo egoísmo, a qualidade pela quantidade, o sentimento do belo pela sensação do luxo plebeu -, essa civilização colocava em risco e à beira do precipício "todas las conquistas de nuestro progreso milenário, toda la herencia acumulada em nuestros veinte siglos de lucha contra la barbarie primitiva." (GROUSSAC, 1898, p. 237).

Há, portanto, todo um vocabulário - democracia, igualdade, anarquia, imprensa diária, folhetim - que marcaria precisamente (Groussac sempre faz questão de delimitar que "hace cién años...”, em referência à Revolução Francesa ${ }^{14}$ ) o momento em que "el rio de la civilización

\footnotetext{
${ }^{13}$ A Guerra Hispano-Americana foi um dos marcos do surgimento de uma corrente hispanista na Argentina, que remetia às tradições ibéricas e à Madre Pátria Espanha, na contracorrente da expansão da influência norteamericana no continente. $C f$. CAPELATO, Maria Helena. A data símbolo de 1898: o impacto da independência de Cuba na Espanha e Hispanoamérica. História. São Paulo, 22 (2), 2003, p. 35-38.

${ }^{14}$ No caso argentino, os primeiros esboços do tema da "questão social" teriam vindo, sempre segundo Groussac, com a geração romântica fundadora da Asociación de Mayo, especialmente na figura de Estebán Echeverría, autor
}

\section{CANPHLAC}

Revista Eletrônica da ANPHLAC, ISSN 1679-1061, №. 21, p. 232-260, Jul./Dez., 2016.

http://revista.anphlac.org.br 
perdía sus ondas em el lecho arenoso". (GROUSSAC, 1898, p. 237). A insistência em demarcar o início da curva descendente do ideal civilizatório traz à tona uma compreensão do tempo cheia de nuances, com uma abertura para um périplo de altos e baixos onde a garantia da satisfação sempre era obrigada a se haver com o temor e a possibilidade iminente da queda. A conclusão é taxativa: Se "desde los primeros siglos, hasta la Revolución Francesa, la ley de progreso se ha cumplido", no presente, "asistimos á una crisis suprema de la civilización." (GROUSSAC, 1898, p. 235-236).

\section{Outros ritmos: experiência do tempo e algumas interfaces}

Há naquela conjuntura letrada, contudo, uma grande variedade de formas de enfrentar essa existência de um novo tempo. Vejamos o caso de Ernesto Quesada (1858-1934) que em uma conferência no El Ateneo em 1895, reivindicava para a nascente "questão social" um caso exemplar do caráter cambiante da história. Foi assim que Roma caíra frente aos bárbaros e, 18 séculos depois, com o esquecimento dessa experiência, o cataclisma da Revolução Francesa colocou novamente a civilização humana em risco. Se rupturas sempre existiram na história, a questão para Quesada seria como cada época buscou reconstruir a ordem após o caos. E daí o grande dilema que surge, pois após um século da onda revolucionária, o abismo que os esperava parecia ainda maior: "Cómo hemos llegado, en menos de un siglo, á exponer á la sociedad al borde de otro abismo, más terrible que el que despedazó el llamado 'viejo régimen'?" (QUESADA, 1895, p. 22)

O principal impacto da "questão social" parece ter sido gerar um impasse na compreensão de que o grande avanço material da civilização seria acompanhado por uma minimização do fosso entre as classes sociais. Pelo contrário. E Ernesto Quesada é taxativo neste sentido:

Si. El mundo marcha. Y por eso han venido desengaño tras desengaño, al ver que los nuevos perfeccionamientos, en lugar de nivelar las diferencias sociales existentes,

do "Dogma Socialista", publicado em 1846. Echeverría teria dado continuidade ao seu mentor Rousseau, o precursor do ideário socialista. Após a obra do filósofo francês, socialismo era o mesmo que ser contrário à liberdade, era a reivindicação do Estado pelo despotismo da maioria. O deslocamento da tirania do uno para a tirania de todos. GROUSSAC, Paul. Estebán Echeverría. La Biblioteca. Tomo IV, 1897, p. 265.

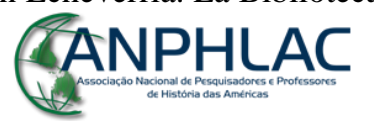

Revista Eletrônica da ANPHLAC, ISSN 1679-1061, №. 21, p. 232-260, Jul./Dez., 2016.

http://revista.anphlac.org.br 
parecían tender á ahondarlas más y más, rebajando las clases menestrosas y exaltando la minoría enriquecida. Qué passa hoy en el mundo entero? (QUESADA, 1895, p.26)

O abalo provocado pela "questão social” nas várias formas de compreensão do tempo foi então digerido de modo a tentar incorporar os novos pressupostos nas estruturas anteriores. Era assim que o professor de Direito Carlos Rodriguez Larreta (1868-1926) analisava as implicações das demandas do nascente socialismo para o tradicional código jurídico. (LARRETA, 1896) ${ }^{15} \mathrm{Se}$, no caso, qualquer estudioso do direito civil identificaria que a mesma filosofia presidiu esse código durante séculos, mantendo estavelmente seus pressupostos de uma teoria fundamental das obrigações, a época contemporânea marcaria uma brusca ruptura. Enquanto "el soplo de ninguna extraña filosofia ha logrado alterar aún el quadro jurídico del sábio emperador romano" (LARRETA, 1896, 560), a tese da imutabilidade do direito civil se desestabiliza frente a uma sociedade convulsionada pela perda de autoridade das antigas instituições:

\begin{abstract}
En la época contemporánea, por la observación de los fenómenos sociales más recientes y con el oído atento á las nuevas doctrinas que han surgido en Europa y que ya se difunden por América, se puede conjeturar que la inmutabilidad del derecho civil se encuentra, por fin, amenazada. (...) Si el socialismo llegase á prevalecer, en la mayor parte por lo menos de las formas concretadas hasta ahora, es indudable que las sociedades futuras tendrían que reformar totalmente la ciencia civil. (LARRETA, 1896, p.561)
\end{abstract}

De início, a postura de Larreta é de rejeição ao ímpeto inovador do socialismo. Aliás, chama a atenção como o autor usa os termos "sociedad moderna", "socialismo" e "cuestión social" indiscriminadamente, sendo automaticamente relacionados uns aos outros. Essas novas diretrizes teriam como eixos a supressão das fronteiras, do sentimento de pátria, o coletivismo e o fim da propriedade individual, além, principalmente, da crítica radical às autoridades institucionais com sua consequente extinção. $\mathrm{O}$ apelo à história aparece para o autor como local de conforto, pois, citando Leão XIII, Larreta entende que Deus deu a terra a toda a linhagem

\footnotetext{
${ }^{15}$ Recordando que, por socialismo, Larreta não se prende propriamente à tradicional dualidade entre "socialismo utópico" e "socialismo científico", mas sim o mobiliza no interior daquele amplo vocabulário capitaneado pela "questão social" que, ao lado de democracia, igualitarismo e outros, representariam o ciclo de inaugurações do "novo tempo".
}

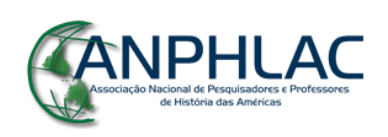

Revista Eletrônica da ANPHLAC, ISSN 1679-1061, №. 21, p. 232-260, Jul./Dez., 2016.

http://revista.anphlac.org.br 
humana, mas não para que eles indistintamente sejam senhores dela. Ele a deixou para a indústria do homem decidir.

Ao longo do texto, porém, a posição de Larreta vai tomando um novo rumo, revelando propriamente as fissuras existentes no interior daquele vocabulário. A abertura ao "cambio", à possibilidade de ruptura com a história, passa a ser considerada de modo mais efetivo. Como o texto foi inicialmente uma conferência proferida na Faculdade de Direito, Larreta afirmava que a Universidade não poderia permanecer de olhos voltados apenas para o passado, abrindo-se para "las necessidades del presente y á las incertidumbres del porvenir." (LARRETA, 1896, p.582), mas principalmente porque grandes pensadores se dedicam a tal doutrina e vinte milhões de pessoas se movimentam nas grandes capitais através da Internacional Comunista. A experiência da história tem aqui então algo a ensinar:

la experiencia de la historia nos enseña que algo debe haber de verdadero y de justo en el fondo de una aspiración que tiene en sí misma fuerza bastante para marchar contra la corriente de las persecuciones, que apasiona á los hombres hasta el delirio, que ha suscitada fanatismos y ya cuenta mártires. (LARRETA, 1896, p.582)

Como pode ser visto, a sedimentação de um novo vocabulário ao mesmo tempo em que sofria restrições, parecia invadir paulatinamente aquele contexto, especialmente no reconhecimento de Larreta da insuficiência das antigas categorias: "Encierran una gran verdad estas palabras de Carlyle: La libertad requiere nuevas definiciones." (LARRETA, 1896, p.583, grifo do autor) A partir desse reconhecimento, a tradição e a imutabilidade de certas instituições estariam à prova do tempo. Aquelas que, no interior "de las agitacciones socialistas" saírem ilesas e alcançarem o porvir, serão propriamente as instituições do direito civil.

Tudo somado, é importante notar que a solução de Larreta para o problema do profundo “cambio" em andamento, novamente a exemplo de seus contemporâneos, é a tentativa de dosar uma teoria da evolução humana que aposta num aperfeiçoamento sem restrições. Ou melhor, o "etapismo" fornecido por uma solução evolucionista da história entra novamente em jogo. Menos que acelerar ainda mais aquela temporalidade, a concepção evolucionista age fundamentalmente como moderação da mesma: "Es indudable que la especie humana se transforma, y que seguirán mudando lentamente las ideas y los sentimientos de los hombres, pero la evolución tiene un límite infranqueable en el orden moral.” (LARRETA, 1896, p.580)

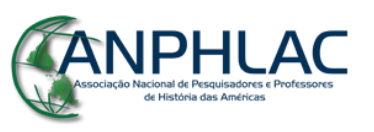

Revista Eletrônica da ANPHLAC, ISSN 1679-1061, №. 21, p. 232-260, Jul./Dez., 2016.

http://revista.anphlac.org.br 
A pluralidade de narrativas presentes em La Biblioteca ganha ainda mais força quando o grande tema do debate público então, a democracia e as formas de incorporação de um novo segmento social àquela comunidade política, é apresentado por um viés particular em comparação com o que vimos até aqui. Trata-se do artigo do historiador e professor da Faculdade de Direito, Francisco Ramos Mejía (1847-1893), irmão, talvez menos conhecido pela crítica, de José María Ramos Mejía. Em um dos seus últimos escritos antes do falecimento, obtidos por Groussac junto à família do autor, Francisco Ramos Mejía descreve um longo percurso histórico intitulado Evolución de la Democracia Argentina, no qual parece apresentar o seu contexto de transformações como apenas o resultado histórico de um grande trajeto de aprimoramento do ethos democrático argentino. Na realidade, o próprio Paul Groussac esclarece em nota que o fragmento exibido na revista é parte de uma obra intitulada $E l$ Federalismo Argentino que Francisco Ramos Mejía não logrou encerrar antes do falecimento. O trecho vinha com o título Fragmento de la historia de la evolución argentina, em que discorria especificamente sobre o processo da democracia colonial.

Como integrante da Unión Cívica Radical e um pouco à revelia dos seus pares, Francisco Ramos Mejía não parecia ver o movimento da "questão social" como algo a ser denunciado, mas sim positivamente incorporado. Sua narrativa sobre a formação histórica da democracia argentina, menos que alertar para as rupturas e tensões trazidas pela "questão social", realçava o potencial integrador que a nação argentina - nascida e formada sob o signo da imigração - poderia oferecer para essa nova massa populacional que vinha construir vida no país.

Seria exemplar, neste sentido, o fenômeno da participação política no período colonial e os canais de intervenção criados pelos Cabildos. Ou seja, para Ramos Mejía havia uma harmonia integradora naquele período que propiciava uma junção entre o elemento europeu e o elemento criollo, de modo que desde muito cedo os oficiais e representantes da Coroa eram obrigados a se haver com as lideranças locais e nativas. Mesmo um processo eleitoral na colônia era resultado da medição de forças entre representantes da coroa e criollos, revelando assim, para Ramos Mejía, uma pré-disposição para uma forma política democrática. Haveria então uma relativa linha de continuidade que só teria sofrido percalços a partir do período revolucionário que culminou na independência argentina. A dissolução dos Cabildos logo após

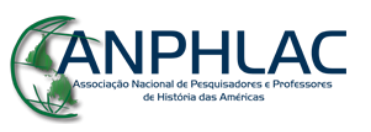

Revista Eletrônica da ANPHLAC, ISSN 1679-1061, №. 21, p. 232-260, Jul./Dez., 2016.

http://revista.anphlac.org.br 
o período de emancipação teria promovido um atraso no aprimoramento daquela forma que se mostrava ajustada à nação argentina:

Este medio y esta escuela los teníamos nosotros durante la colonia en la institución de los Cabildos; y aún cuando en forma incompleta, esta habría ido perfeccionándose sucesivamente como todo lo humano. Era esa una tarea que incumbía a la posteridad. (RAMOS MEJÍA, 1897, p. 171)

Índice também dessas disputas em torno da "questão social", da democracia e das formas de experiência do tempo, é a apropriação que Francisco Ramos Mejía faz da obra de Tocqueville. Se, como foi possível ver aqui, o escritor francês era chamado à cena fundamentalmente como alerta aos danos provocados pela ideologia da igualdade, Ramos Mejía interpreta a obra de Tocqueville como um convite à democracia e ao alargamento da esfera política, de modo que o grande valor da obra seria identificar que não é a eleição do presidente e do congresso pelo sufrágio que faz livre o povo norte-americano, mas sim a participação que toma o povo mesmo em todos os assuntos da sociedade:

Tocqueville, en su obra sobre la Democracia de América, considera como fuente de la libertad y de la seguridad americana, no tanto la elección del Presidente y del congreso por el sufragio popular, cuanto la participación que toma el pueblo mismo en todos los asuntos de la sociedad, al intervenir directamente en la administración de los pequeños detalles del gobierno comunal. (RAMOS MEJÍA, 1897, p. 171)

Ainda que estejam pontuadas essas particularidades de Francisco Ramos Mejía na sua maneira de apreender o movimento da história e a expansão do debate sobre a "questão social", sua intenção não parecia ser aquela de acelerar ainda mais o desenrolar daquela situação. Sendo o ethos argentino historicamente acolhedor para com o imigrante, caberia àqueles agentes deixar o tempo dar conta do processo de incorporação daquela massa. Certamente que essa solução parece mais otimista que aquela de Miguel Cané, por exemplo. No entanto, destaca-se novamente o apelo pela contenção daquele ímpeto transformador na forma de "etapas" a serem cumpridas. Se ainda não é tão perfeita quanto à democracia existente nos Estados Unidos, a democracia argentina estava cumprindo seu papel de aprimoramento que, deixado à sua velocidade, resolveria seus impasses:

\section{GANPHLAC}

Revista Eletrônica da ANPHLAC, ISSN 1679-1061, №. 21, p. 232-260, Jul./Dez., 2016.

http://revista.anphlac.org.br 
Cualesquiera que sean los títulos con que el siglo XIX se presente á disputar la primacía sobre sus antecesores, ninguno será más luminoso que el de haberse realizado en él la constitución definitiva de la grande y fecunda democracia americana. No tiene ésta, la nuestra, modesta y trabajada, es aspecto imponente de su congénere del norte; pero ha contribuido y contribuirá como ella al resultado general que la evolución humanitaria ha producido y producirá en este gran fenómeno político y social. (...) Á la democracia argentina nada le hacen perder de su importancia como factor de la evolución humana, sus inmensas penumbras, sus grandes deficiencias, sus lagunas y sus errores. (RAMOS MEJÍA, 1897, p. 199)

A proposta de uma solução "afetiva" e amalgamadora de Ramos Mejía acentua a variedade dos modos de lidar com a "questão social" naquela conjuntura. Aqui, menos que sintoma de decadência, a questão é tomada como um desafio para os argentinos. No interior de todos aqueles diagnósticos da crise, é como se Francisco Ramos Mejía apresentasse aos seus pares outra saída que apenas aquela do lamento pela velocidade das transformações cotidianas. Em La Biblioteca, o tempo e a história assumem diversas faces. Desde aquela em que o duro correr das transformações parecia esvaziar toda experiência, até aquela - mais otimista e menos dolorosa - em que esse mesmo correr poderia significar a realização de um ideal de aperfeiçoamento.

Democracia, igualitarismo, aceleração, etapismo, os significados do jornal e da revista na nova sociedade industrial nascente, dentre outros sintomas e temas discutidos neste texto, assumem a forma de termômetros de uma dada experiência do tempo. O mais interessante, por sua vez, estará não em afixar interpretações conclusivas e redutoras, mas especialmente ver a sutileza dessa multiplicidade de experiências aqui relatadas no que diz respeito às modulações e interfaces que cada uma oferece, bem como os rearranjos do passado e a capacidade de determinados sujeitos em vislumbrarem futuros possíveis.

Assim, foi possível observar que falar em experiência do tempo pressupõe, necessariamente, estar atento a determinados ritmos impostos ao tempo como, por exemplo, no desejo de Miguel Cané pela moderação e pelo caráter processual das rápidas transformações sociais trazidas pelo industrial século XIX. Ou, por certo, no âmbito inverso, quando Francisco Ramos Mejía acredita que tais transformações, em especial a acentuação da questão democrática, deveriam ser intensificadas a ritmos ainda mais acelerados. $\mathrm{O}$ olhar sobre estes

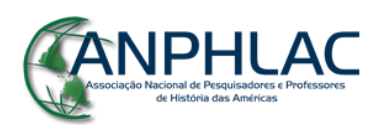

Revista Eletrônica da ANPHLAC, ISSN 1679-1061, №. 21, p. 232-260, Jul./Dez., 2016.

http://revista.anphlac.org.br 
distintos ritmos do tempo tornou possível, além de afastar análises holísticas, assimilar um dado contexto pela sua pluralidade constituinte, em particular ao retirar a camada de certezas que recobre algumas interpretações, para abrir espaço às dúvidas, aos temores, ao sentimento de perda e esfacelamento da experiência, como recorrentemente alertou o diretor de La Biblioteca, Paul Groussac.

\section{Referências Bibliográficas}

BARTHES, Roland. $O$ último escritor feliz. Trad. Juliana Bratfisch. Belo Horizonte: Edições Chão da Feira, n 30, 2014.

BERTONI, Lilia Ana. Construir la nacionalidad: héroes, estatuas y fiestas patrias, 1887-1891. Boletín del Instituto de Historia Argentina y Americana "Dr. Emilio Ravignani", Tercera Serie, n. 15,1 semestre 1992 .

BIAGINI, Hugo. Cómo fue la Generación del 80. Col. Esquemas Históricos, Bs. As.: Editorial Plus Ultra, 1980.

BRUNO, Paula. Paul Groussac: um estratega intelectual. Buenos Aires: Fondo de Cultura Económica, 2005.

CANÉ, Miguel. Nuevos Rumbos Humanos. La Biblioteca, Tomo I, 1896.

CAPELATO, Maria Helena. A data símbolo de 1898: o impacto da independência de Cuba na Espanha e Hispanoamérica. Historia. São Paulo, 22 (2), 2003, p. 35-38.

DEVOTO, Fernando. Historia de los italianos en Argentina. $2^{\circ}$ ed. Buenos Aires: Biblos, 2008.

DONGUI, Tulio Halperín. Proyecto y Construcción de una Nación. Caracas: Ediciones Biblioteca Ayacucho, 1980.

GARULI, Liliana. Documentos de historia argentina (1870-1955). Buenos Aires: Eudeba, 2011.

GOLDGEL, Víctor. Cuando lo nuevo conquistó América. Prensa, moda y literatura en el siglo XIX. Buenos Aires: Siglo XXI, 2013.

GROUSSAC, Paul. La paradoja de las ciencias sociales. La Biblioteca. Tomo II, 1896.

GROUSSAC, Paul. Documentos Historicos. La Biblioteca. Tomo II, 1896.

\section{GANPHLAC}

Revista Eletrônica da ANPHLAC, ISSN 1679-1061, №. 21, p. 232-260, Jul./Dez., 2016.

http://revista.anphlac.org.br 
GROUSSAC, Paul. Génesis del Heróe. La Biblioteca. Tomo III, 1897.

GROUSSAC, Paul. La Educación por el Folletín. La Biblioteca. Tomo VI, 1897.

GROUSSAC, Paul. Estebán Echeverría. La Biblioteca. Tomo IV, 1897.

GROUSSAC, Paul. Por España. La Biblioteca. Tomo VIII, 1898.

KOSELLECK, Reinhart. Futuro Passado. Rio de Janeiro: contraponto, 2006.

KOSELLECK, Reinhart. Progreso y decadencia. In: Historia de conceptos. Estudios sobre semântica y pragmática del lenguaje político y social. Madrid: Editorial Trotta, 2012.

LENZ, Mario Heloisa. Crise e negociações externas na Argentina no final do século XIX: o início da insustentabilidade do modelo aberto. Economia e Sociedade, Campinas, v. 15, n. 2, 27ago. 2006, p. 375-399.

PALTI, Elías José. Aporías: tiempo, modernidad, historia, sujeto, nación, ley. Buenos Aires: Alianza, 2001.

PALTI, Elías. El momento romántico: nación, historia y lenguajes políticos en la Argentina del siglo XIX. Buenos Aires: Eudeba, 2009.

RAMOS, Julio. Desencuentros de la modernidad en America Latina: literatura y política en el siglo XIX. México: Fondo de Cultura Económica, 1989.

RAMOS MEJÍA, Francisco. Evolución de la democracia Argentina. La Biblioteca. Tomo V, 1897.

SANTOS, Fabio Muruci. Arielismo e liberalismo nos escritos de viagem de Miguel Cané e Oliveira Lima. Revista Anos 90, Porto Alegre, v. 16, n. 29, jul. 2009, p. 125-153.

SHUMWAY, Nicolas. A invenção da Argentina: História de uma ideia. São Paulo: Editora da Universidade de São Paulo; Brasília: Editora UnB, 2008.

TERÁN, Oscar. Vida intelectual en el Buenos Aires fin-de-siglo (1880-1910). Buenos Aires: Ed. FCE, 2000.

WEINBERG, Félix. El pensamiento de la generación del 80. Cuadernos del Sur, núm. 13, Universidad Nacional del Sur, 1980.

WEINBERG, Gregorio. La ciencia y la idea de progreso en América Latina, 1860-1930. Buenos Aires: Fondo de Cultura Económica, 1998.

\section{CANPHLAC}

Revista Eletrônica da ANPHLAC, ISSN 1679-1061, №. 21, p. 232-260, Jul./Dez., 2016.

http://revista.anphlac.org.br 